Öz

Bu makale, yükseköğretimdeki endüstri ürünleri tasarımı bölümlerinde yürütülebilecek elektromekanik ürün uygulamaların temel alan disiplinler arası eğitim aktiviteleri hakkında bilgi vermekte, ögrencilerin bu tür aktivitelere ilgi ve beklentilerini araştırmaktadır. Bu aktiviteler çeșitli dersler bünyesinde gerçekleştirilmekte olup genellikle elektro-mekanik bir endüstri ürününü oluşturan parçalar, bunların montajları, ürün teknolojileri, 3 boyutlu modelleme, elektronik, yazılım, donanım, prototip yapımı gibi konulara

yoğunlaşmaktadır. Derslerde öğrenciler çeşitli ürün teknoloji ve sistemleri konusunda bilgilendirilmekte, bunları gerçek parçalarla bir araya getirip çalıştırdıktan sonra tasarladıkları ürünlere uyarlamaktadırlar. Bu çalıșma ile öğrencilerin, ürün içyapı ve teknolojilerinin ürün dıș tasarımına etkisi hakkında bilgi ve deneyim kazanmaları hedeflenmektedir.

Makalede öncelikle dünyadaki benzer yönelimler ve ilgili akademik literatür incelenmiştir. İzleyen sayfalarda çalıșmada yer alan aktivitelerinin yapısı ve uygulanışı açıklanmıştır. Sonrasında öğrencilerin disiplinler arası aktivitelerle ilgili düşüncelerini ortaya koymak amaciyla yapılan alan çalışması anlatılmıștır.

Alan çalışması sırasında yapılan analizlere girdi olarak, öğrencilerle yapılan görüşmelerde doldurulan likert ölçekli özel hazırlanmıs formlar yardımıyla toplanan veri kullanılmıştır. Bu veri faktör analizi yöntemi ile işlenerek öğrencilerin disiplinler arası çalıșmaya ilgi düzey ve beklentilerini belirleyen faktörler ortaya çıkartılmıştır. Makalenin son bölümünde faktör grupları ve diğer bulgular yorumlanmıș, elde edilen sonuçlar listelenmiştir.

Abstract

This article provides information about multidisciplinary educational activities based on electromechanical product applications that can be conducted in university industrial product design departments and investigates the interests and expectations of students in such activities. These activities are carried out in various lectures and generally focus on the parts that make up an electro-mechanical industrial product, their assembly, product technologies, 3D modeling, electronics, software, hardware, prototyping. In the lessons, students are informed about various product technologies and systems, they are put together with real parts and they are adapted to the products they design. With this study, it is aimed that the students gain knowledge and experience about the effect of product internal structure and technologies on product exterior design. In this article similar orientations in the world and related academic literature are examined first. The following pages describe the structure and implementation of the activities in our study. Afterward, the field study which was conducted to reveal the students' thoughts about multidisciplinary activities is explained.



This work is licensed under a Creative Commons Attribution-NonCommerci 4.0 International License.

\title{
Investigating Industrial Design Students' Expectations from Technically-Oriented Courses: With a Case Study on Electro-mechanical Applications
}

D Özkal Hüseyin Özsoy Mimar Sinan Güzel Sanatlar Üniversitesi, Endüstri Tasarımı Bölümü

Başvuru tarihi/Received: 14.09.2019, Kabul tarihi/Final Acceptance: 16.09.2019

\section{Introduction}

This paper investigates interdisciplinarity as a facilitating factor in collaborative design process and proposes a framework for establishing a design environment which helps industrial designers to integrate different disciplines into the design process. The framework helps the industrial designers to oversee their designs with more attention to technical requirements and also enables professionals from other disciplines to easily join the process. The study is demonstrated on a field study of electromechanic applications in industrial design education which consisted of various lectures and other related activity we performed at our department in the university between 2016 and 2019. The research data is collected from students who took part in lectures and workshops, and later processed by using factor analysis methodology, revealing a number of factors which affect the efficiency and outcome of the studies. Finally the findings are interpreted and suggestions are given to designers and design researchers.

With the need of matching the global competition and the help of new computing technologies adapted from other disciplines, the product design process continues to improve exponentially
(Oakes, Felton, \& Garner, 2006:567-579). So industrial design education should also give the required importance to better preparing the students for these changes at the professional industrial design world (Yarimca, 2011:1-22). On many occasions, there seem to be gaps between the real business world and what is taught at school (Wang, 2008:851-854). The traditional design education curriculum aims to give students the abilities, which are used for solving known specific design problems. During their education, design students usually experience minimal fieldwork similar to what awaits them in their future professional careers. This becomes very problematic when they become new recruits and still need to spend considerable extra time to improve themselves and meet their firms' requirements (Oakes et al., 2006:567-579). To enable future design professionals to have the necessary requirements at graduation, industrial design education should be improved (Oakes et al., 2006:567-579).

The phenomenological observation of people's daily activities shows that they require a continuous flow of experience and information from many different fields. As industrial designers are required to professionally design and develop new experiences for people, interdisciplinarity 
Data collected in interviews by selecting grades on specially prepared Likert scale forms were used as input to the analysis conducted during the field study. This data was analyzed by factor analysis method and the factors determining the level and expectations of students' interest in multidisciplinary studies were revealed. In the last part of the article, factor groups and other findings were interpreted and the results were listed.

Anahtar Kelimeler: Endüstri tasarımı eğitimi, tasarım uygulamaları, disiplinler arası çalışmalar, ekip çalışması, akıllı ürün tasarımı, faktör analizi.

Keywords: Industrial design education, design applications, multidisciplinary studies, teamwork, intelligent product design, factor analysis. is a prominent factor to be considered in industrial design (Nicolescu, 2005:11). As product designers want to create preferred experiences or turn any existing experience into a better one, they need to understand how these experiences occur; therefore, they need to know multiple phenomena belonging to various fields related to people. This leads to interdisciplinarity as it happens when a 'common axiomatic for a group of related disciplines is defined at the next higher hierarchical level or sub-level, thereby introducing a sense of common purpose (Jantsch, 1972:7-37). During any interdisciplinary work, problems will be a challenge for each discipline with diverse methods, terminologies and knowledge that transcend the boundaries of the involved disciplines (Gibbons, 1994). As it is the case in industrial design in which encountered design problems are solved by using methods or concepts shared with or borrowed from other disciplines (Nicolescu, 2005:11); During their daily work designers and researchers frequently get help from other disciplines and therefore their professional activities are naturally interdisciplinary (Findeli, Brouillet, Martin, Moineau, \& Tarrago, 2008:67-91). Concerns of manufacture, assembly, disassembly, and recycling necessitate an innovative approach to be employed in industrial design. The requirement to have more control over the overall product design process necessitates the industrial designers to work on various interdisciplinary tasks (Sonnenwald \& Lievrouw, 1997:179-204). As it is not possible for an industrial designer to have adequate knowledge in every task, he/she needs to be able to work together with professionals of other disciplines. Therefore interdisciplinarity should also be an important consideration in university education in which future industry professionals are trained (Srinivasan, Lovejoy, \& Beach, 1997:154-163). Cooperation between design, engineering and other departments becomes much easier if interdisciplinarity is experienced during university years (Itkonen, Ekman, \& Kojo, 2009:263-271).

Before putting together the basic rules and further structural details of an interdisciplinary framework for industrial design education, carefully studying the earlier studies would certainly be very helpful.

\section{Literature Review}

It is seen that literature studies mostly start by investigating the requirements of employers in the industry. For instance in his work, Kai Wang gathered data from the job advertisements published on four online recruitment websites in the People's Republic of China and used descriptive analysis to categorize the qualifications required from industrial designers. By evaluating his findings, he stated that product design education should specifically put focus on the expertise required more by the industry (Wang, 2008:851-854). Similarly Lowden et al. investigated employers' preferences for employee skills and stated that there is a considerable mismatch between the university education subjects and the demands of the industry and made recommendations to the universities to improve their course selection criteria (Lowden, Hall, Elliot, \& Lewin, 2011). Weligamage and Siengthai, made a similar study using data they gathered by surveying employers, unemployed graduates, employed graduates, current university students, and university faculty members in Sri Lanka about industry requirements and university education capabilities. They pointed out the mismatch between employer needs and university graduates' capabilities and proposed ways to improve the situation (Weligamage \& Siengthai, 2003). Findeli et al. also researched design and interdisciplinarity with special emphasis on quick tentative contributions to the methodology of design research. They presented a case study about the needs of consumers with Alzheimer's disease and proposed an increased use of interdisciplinary during the design process for achieving better solutions (Findeli et al., 2008:67-91).

A number of studies which have been done in Turkey helped us to better understand our own requirements. For instance, 
Erkarslan et al. did a study to ascertain the Turkish industry's perceptions of industrial designers' role in business by analyzing the industrial designers' qualifications investigated at online recruitment resources. They produced a comprehensive list of design-related and interdisciplinary qualities sought by the industry and concluded that the education system should be in continuous self-revision for conforming to the ever changing industry needs (Erkarslan, Kaya, \& Dilek, 2013:129-145). Kındı investigated the Turkish industry for industrial designers' employment characteristics by surveying ID employees from various firms and pointed out that, capabilities like interdisciplinarity, management, and organization are currently more valued in the future Turkish industry. She concluded that these capabilities will be sought more in the future and industrial designers need to improve themselves accordingly (Kindl, 2007).

Several investigated studies related to industrial design education are as follows. Başar and Ülkebaş investigated the diversity of industrial design education in Turkey by analyzing the undergraduate education programs. They concluded that the industrial design education in the country needs to adopt itself to the transition in professional design circles towards increasing the interdisciplinary design thinking (Başar \& Ülkebas, 2011:981987). Cartier performed a study by interviewing Turkish industrial design students to investigate and evaluate their thoughts and expectations on design and education issues. She concluded that students want to have more creative activities covering a diverse list of subjects during their education (Cartier, 2011:21872191). Erkarslan reviewed the relations between design education and industry in Turkey. He used SWOT analysis to determine the strong and weak aspects of industrial design education in terms of satisfying industry needs, and presented valuable remarks and conclusions

(Erkarslan, 2013).
As Factor Analysis was the processing method preferred for this study, several relevant studies using the same method are investigated in detail. The first one was done by Sloka et al. by analyzing Latvian firms' professional requirements from qualified employees. They used Factor Analysis, supported by KruskalWallis non-parametric statistical test, and concluded that to produce the workforce necessary for the global economies, the education system should closely follow and quickly adopt to the changes in professional environments (Sloka et al., 2015:69-75). Tsitskari et al. researched the employers' skill expectations in the sports and recreation industry. They applied Factor Analysis to data gathered from 193 employers and produced a list of important factors determining the required skills. Finally they interpreted the implications each factor and listed prerequisites for better developing the necessary skills (Tsitskari, Goudas, Tsalouchou, \& Michalopoulou, 2017:1-9). Representing a study conducted with a different viewpoint, Etemoğlu researched the motivational drives of industrial designers employed in Turkish firms by using factor analysis. She determined their motivation sources with great detail, pointing out that professional satisfaction is a stronger drive for Turkish industrial designers (Etemoğlu, 2013).

After completing the literature review, we planned to do our research concurrently within our regular lectures, starting with a single lecture and improve the study in the following years by adding new ones, and supporting them by additional surveys and workshops. As we went along through the semesters, we gathered data from student opinions to determine the outcomes of the study.

\section{Courses on Electro-Mechanical Applications in Industrial Design}

The initial establishment of the interdisciplinary framework proposed in this article had been started by a lecture named "Electro-mechanical applications in industrial design", in which the use of selected industrial product technologies 
were demonstrated to the students with hands-on experiments to enable them to know more about the products' interior requirements. In the following semesters the study improved by the introduction of "Intelligent product technologies" lecture, which is about software technologies which was followed by "Production oriented computer-aided design" lecture which is about products' interior mechanical details (Author, 2018). In these lectures, design students are informed about the interior electro-mechanic parts and systems that perform the actual functions of a product and their relations to the exterior product case giving the product its form and user interfaces while simultaneously housing and protecting the internal mechanisms. Later on, two graduate lectures, "Product software design" and "Product software management" are initiated, aiming to give information about the use of software technologies embedded in many of today's products. The interdisciplinary environment in the class is established by accepting students from various departments such as industrial design, engineering, ceramics, architecture, graphics, photography, and sculpture.

In lectures, technical concepts such as electrical energy, electronics, embedded information technologies, software, mechanisms, automation, and computeraided design-manufacture are discussed in a designer friendly language suitable for design students who mostly attended to a limited amount of science-related lectures previously. With this transfer of information and accompanying hands-on experiments, it is aimed to develop new student abilities such as;

- Efficient interdisciplinary communication and cooperation during team work.

- The use of high technology tools such as embedded programmersemulators and their software.

- Evaluate and test virtual product designs by using simulation software.

- Have hands-on experience with prototype building.
- Foresee possible issues that might arise in production much earlier in the design process.

- Understand and experiment with the interdisciplinary design process.

After the first year of our studies, the information and the experience we gained had been presented in two symposiums, feedback from other scholars was obtained and used for improving the framework (Author 2011, Author 2012). The overall study performed and the lectures it contains are summarized for every semester at the following sections 2.1-4.

\subsection{First Semester}

Conforming to the general subject of the project studio of this semester, which was "white home appliances", various consumer products are investigated and in each class, a different product was focused on. During the lecture, a presentation made about its technologies, internal structure, components, and development history. Then the students are asked to design a similar white home appliance of their selection, with special emphasis given on its interior electro-mechanical details by using information that they are given (Figure 1). During this application, the design of the product form and other exterior details are completely left to the students, as long as the product shell is able to house the mechanical parts and the electronics inside. Finally, the design

Bicycle lighting product "Bikelight" designed by the instructor.
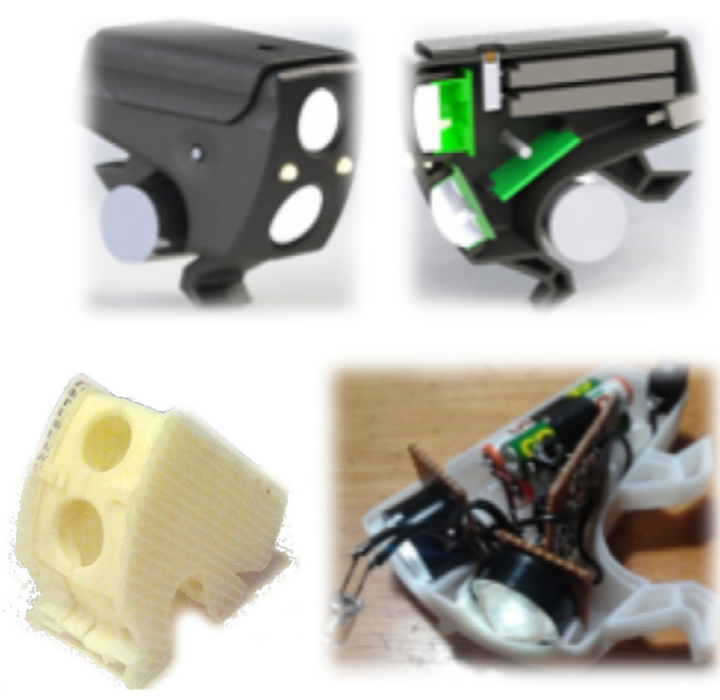



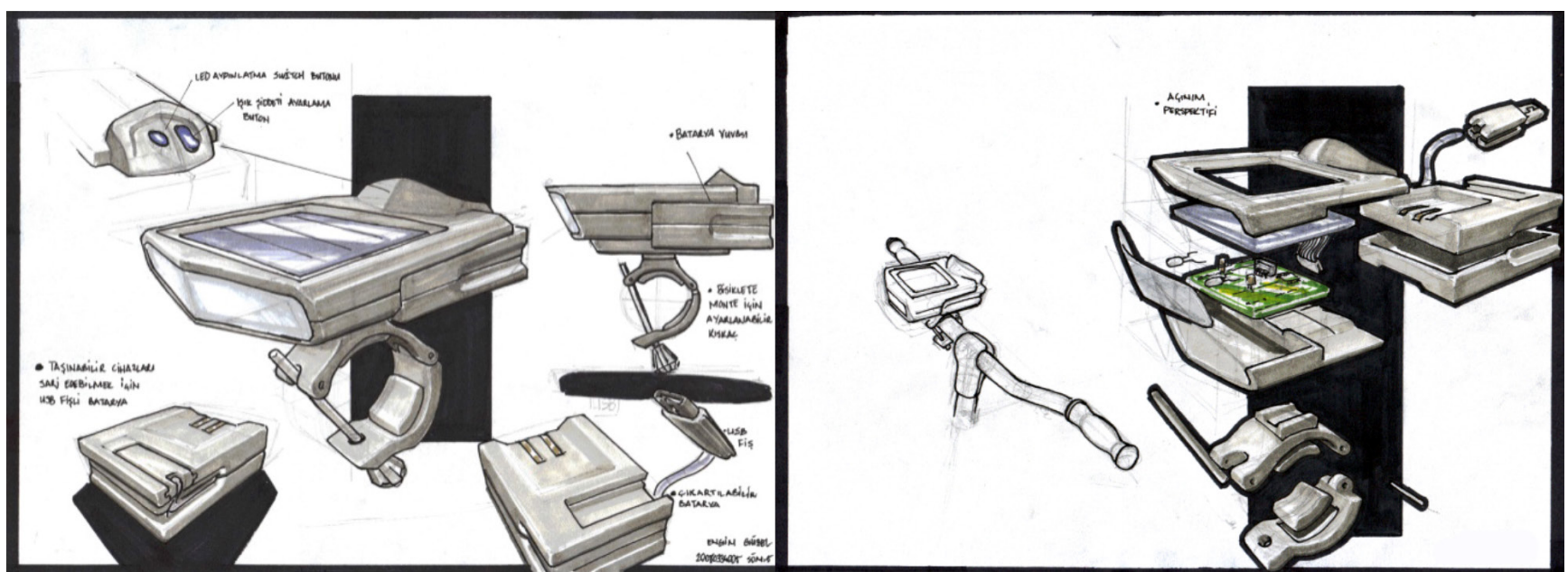

Figure: 2

Bicycle lighting product designed by a student. sketches are examined and their feasibility discussed (Figure 2).

\subsection{Second Semester}

As the students have completed the first semester and learned basics of electromechanics, they are given a more complex design project. The lecture's focus and method is changed to enable students to have more hands-on experience through experiments. The product concept is announced as a handheld search and rescue equipment to be used after natural disasters and the detail level of the final design is aimed to be adequate for prototype production. Initially relevant products on the market, such as hand megaphones, portable electric torches, walkie-talkies etc. are investigated. Then a portable mini megaphone is purchased, disassembled and its internal structure is examined inclass: interior electronics are taken out of the product casing and solely the internal parts are reassembled and operated on the desk. During this experimentation, the connections and other assembly details between parts, their purposes, the relations between the internal structure and the product form, space required by the functional parts are presented to the students. Later disassembled parts of the product are distributed among the students to be 3-D modeled complete with important details and correct dimensions. Then the students are given the task of designing search and rescue products of their own. Prior to and during the sketching process, 3 -D computer models of the parts which were made previously are used by students in pc software to test different assembly variations. This helped the students to see if their designs could contain all the interior parts and in case they could not, the students made the necessary corrections at their sketches before going further into the design process. Later, three of the produced sketches are selected to be further developed as a team work. Small foam mock-ups of the product forms are made to have the feel of the products at hand by doing some manual testing and do the necessary corrections in design details. During this, the students are also instructed about injection molding, ABS plastic parts manufacturing, and the details important for assembly.

In later weeks, whole parts of the designed product are 3-D modeled in Solidworks software and virtually assembled with the previously modeled electro-mechanic interior parts (Figure 3). Finally, finished body parts are 3-D printed, electromechanics installed inside obtaining several assembled products to be tested and used by the students.

\subsection{Third Semester}

New products are selected and some changes to the lecture structure were made to enable more hands-on applications. Experiments are planned in a way 



to enable simple electro-mechanical product systems to be built on electronic prototyping boards and then products to be designed based on these systems. In the lectures, the students are instructed about component names, physical properties, pin numbers, values, coding systems, and they are given a list of them to be purchased from the market. Mistakes made during purchasing forced some students visit the markets several times and made them to pay better attention later on. Purchased electronic components are shuffled up and placed in a big box. Before each experiment, the students are asked to search the box and find the components in the circuit schematic of the experiment, getting the students more accustomed to working with electronic components.
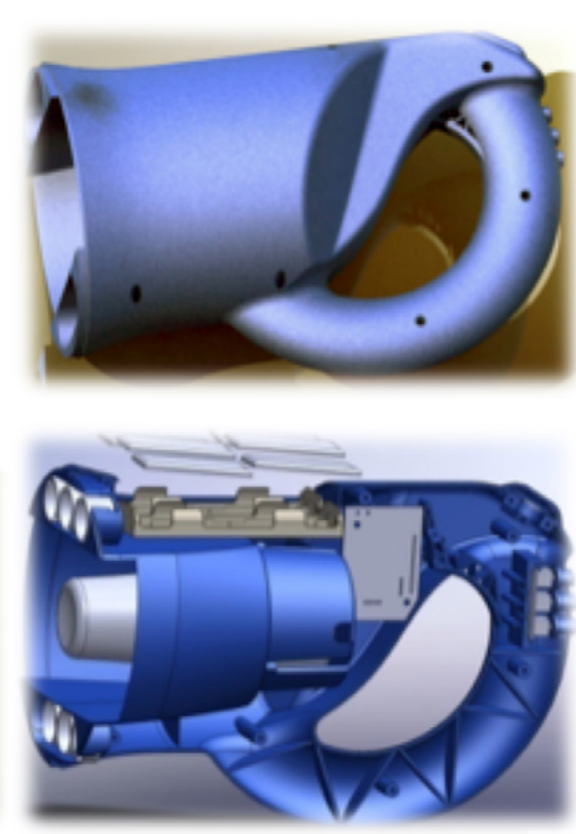

Initially all circuit experiments are demonstrated to the students as computer simulations before being assembled from actual components on proto-boards. These simulations gave the students the opportunity to test the operation of product's electro-mechanical operations without causing any component damage.

The first test circuit produced and operated in class was a keychain light. Initially a running prototype that was previously designed and produced by using 3-D printed plastic parts is shown to the students (Figure 4). The circuit designed for this prototype is also used for the products designed and built by the students later on (Figure 5).

After assembling and running the interior circuit of the product on electronic
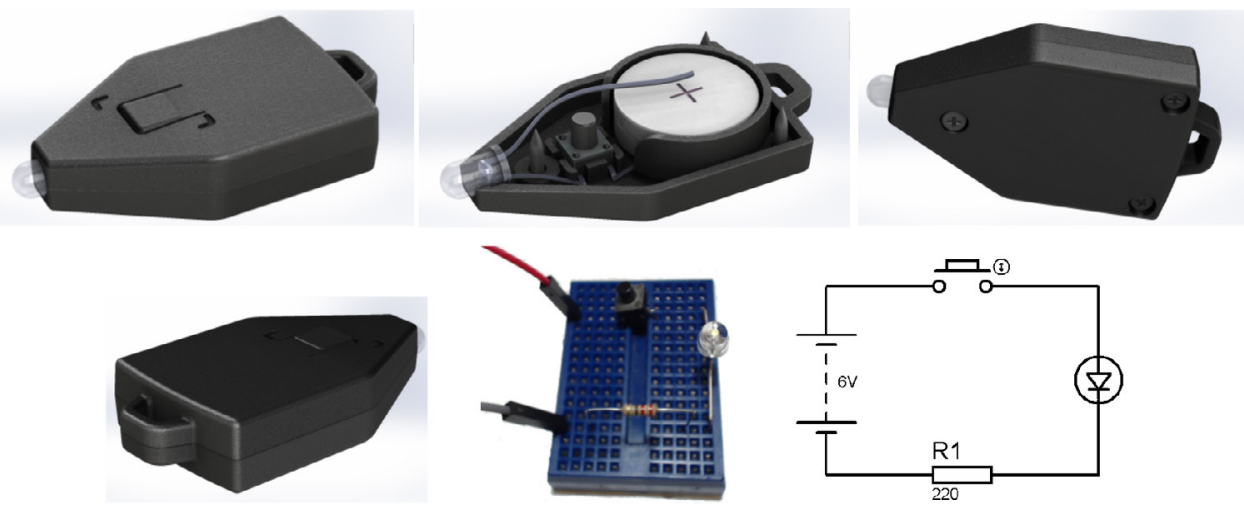

Figure: 3

Search and rescue product "Rescume",

designed by the instructor.

Figure: 4

Led keychain product "Keylight" and its circuit schematic, designed by the instructor. 
Figure: 5

Various prototype products designed and built by the students.

Figure: 6

solar charged torch functional mock-up built by a student.
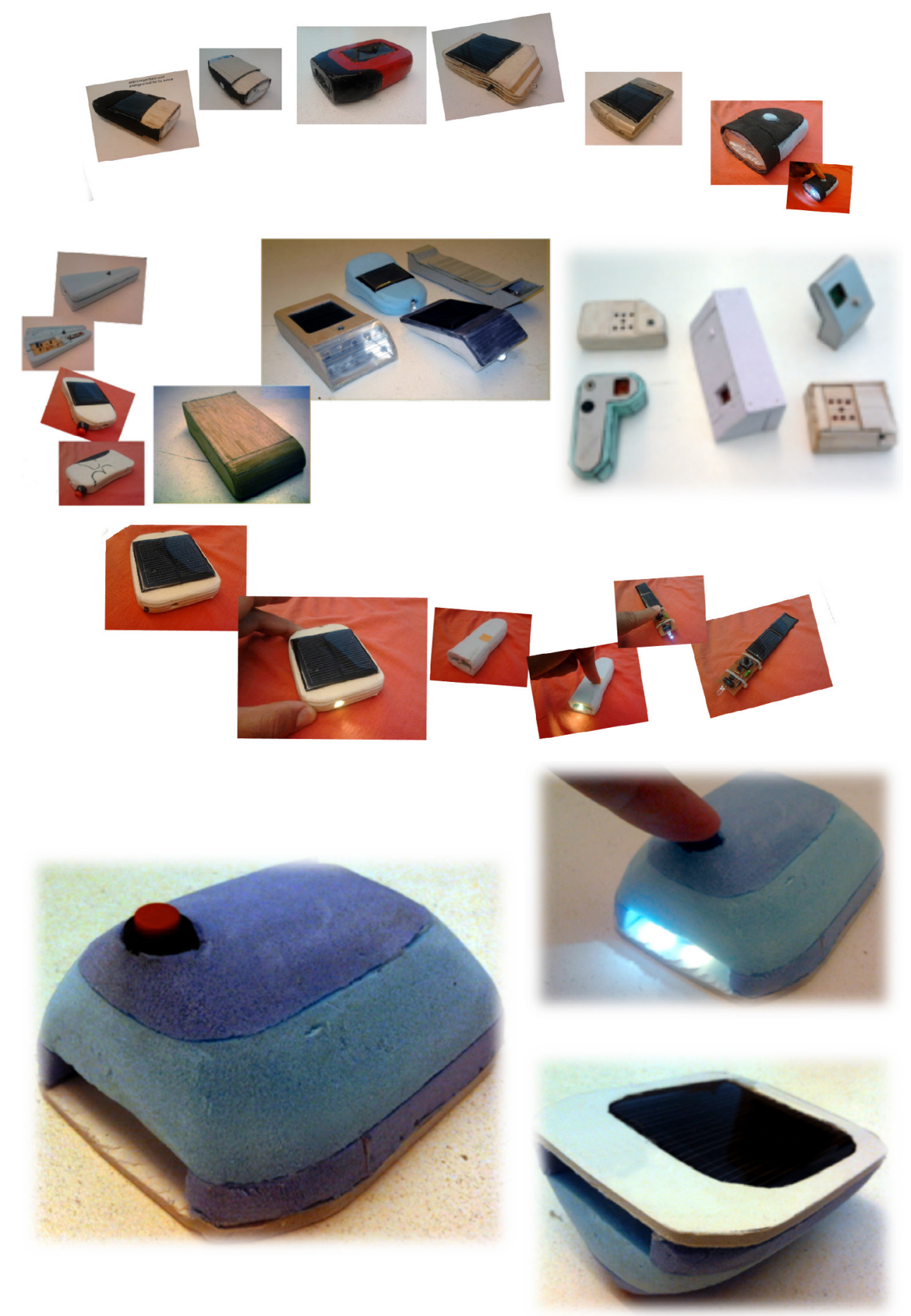

prototype boards, the students are briefed about the product's internal mechanical properties and the necessities for simple assembly and manufacture. Then they are asked to design their own hand-torch designs. When completed, the designs are 3-D modeled with details adequate for producing prototypes and the students are tasked with having those parts built with 3-D printing or other methods and assembling them to running condition. In later weeks, various products with simple electro-mechanics, performing useful and fun tasks were designed, 3-D 
modeled and built. All these products are manufactured as either hand built or 3-D printed mock-ups and prototypes with operational circuits installed inside (Figure 4-6).

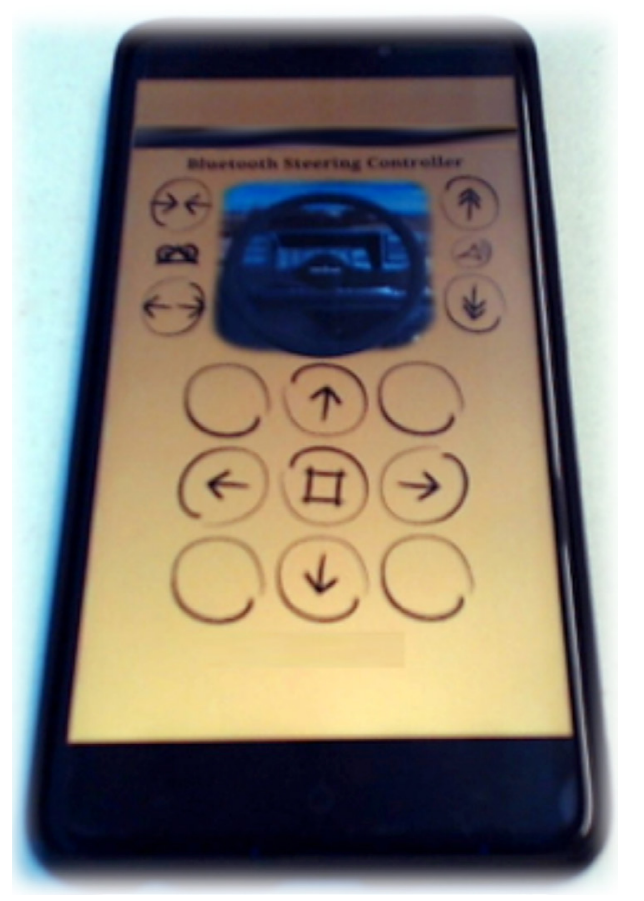

\subsection{Fourth and Later Semesters}

Two new lectures are introduced; "Intelligent product technologies" and "Software in products". The contents of these lectures are prepared about information technologies, which take up a good part of today's products. The lectures are structured with the purpose of giving the design students an understanding of hardware and software technologies in high-tech products such as tablets, cellphones, mp3 players, cameras, game consoles, computers etc. Lecture subjects are also selected from software topics, which are widely applied to intelligent products such as algorithms, flowcharts, software procedures, artificial intelligence, etc. These subjects are explained by using examples from daily life activities, such as preparing algorithms and flowcharts for coffee making or cooking. Concepts like programming, integrated development environment, embedded software, compiling, debugging, and running are explained to the students and they are also given the opportunity to go deeper into the programming by better
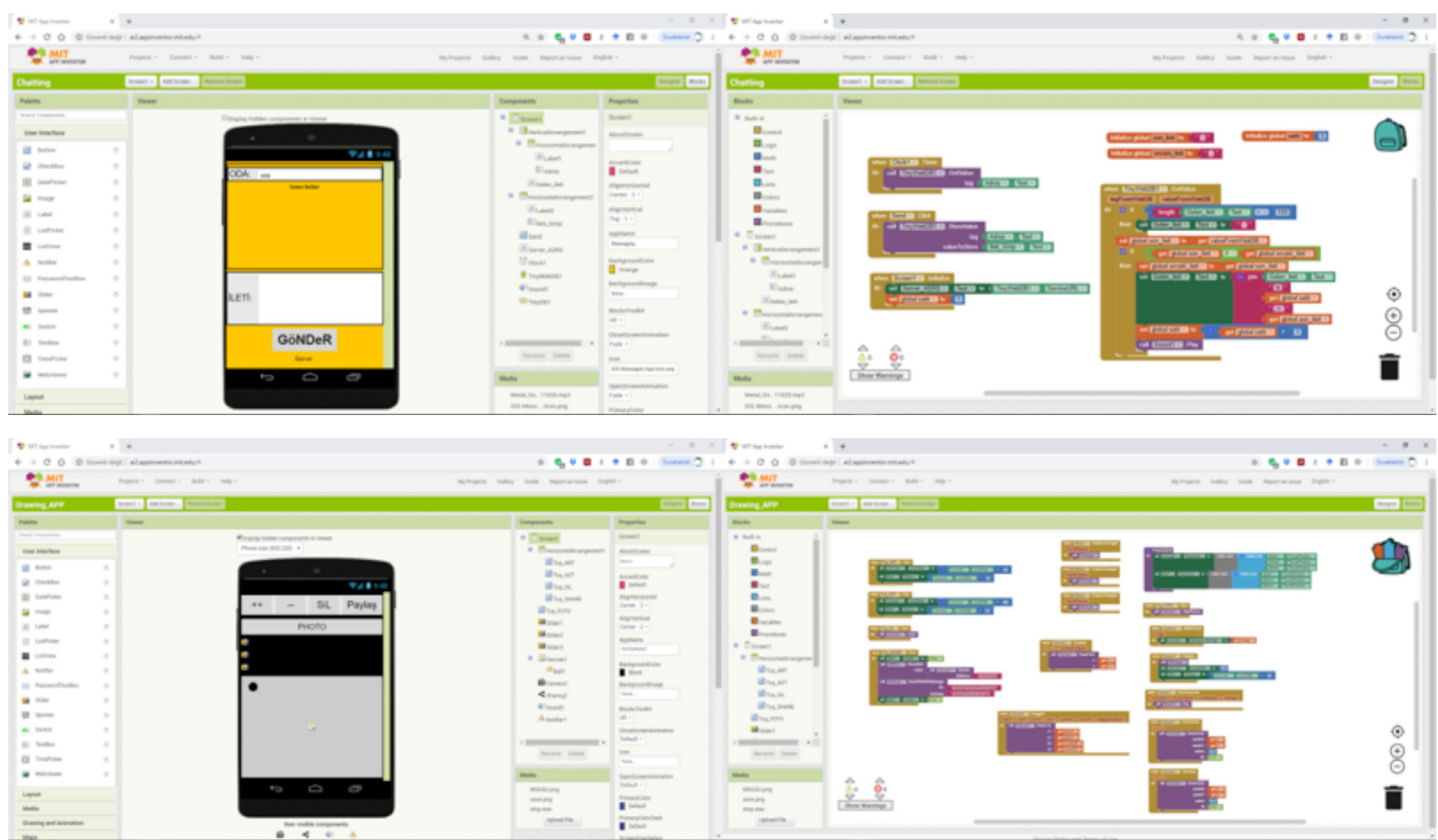
learning programming languages and write product software in the future. For experimenting, several intelligent product functions are converted into algorithms, formed as flowcharts and the code written in $\mathrm{C}$ language to implement them are examined and explained. In the following lectures, a new programming language; The Application Inventor, developed by Massecussets Institute of Technology is introduced to the students, which is a complete programming environment especially suitable for industrial design students with its block based graphical programming. Initially sample android applications are demonstrated such as the ones in Figures 7-8, and 9 then the students are allowed to make, test, and use their apps for their phones. Finally, Android gaming applications are designed and programmed by students on the Application Inventor.

\subsection{Technologies Used in This Study}

The phases of our study can be summarized as four distinct steps utilizing separate technologies. Different product aspects are discussed and experimented
Figure: 10
"RetroGame", a handheld gaming product designed by the instructor ( $3-D$ model in solidworks window). in each step; the first product aspect is the products' exterior body shell, which carries form and user-interface. The next one is the "product mechanics"; the group of interior structure details that support the operational interior parts of products and connect them to the body shell internally. The third is the operational electromechanic parts inside, which perform the product functions. The last product aspect to cover is the software code that runs inside the product firmware, controlling all other parts and in fact the overall product.

Several PC programs are used during the study. Solidworks 2014 is used for modeling the exterior details as well as the interior mechanics. It is suitable for its ability to work on parts and assemblies, to simulate general motion and mechanical systems and to provide ready to manufacture results. By the use of the Solidworks program, students could easily transfer their designs from sketches to computer models. In the Solidworks environment, students could simulate and test the mechanical properties of product parts, taking necessary precautions to prevent undesired internal interferences (Figure 10). This modeling work also enabled students to be ready to produce the product bill of materials, assembly planning and parts' relations documents when needed, as these are the outputs that can be automatically generated by Solidworks with one mouse click.

Another important part of our study is the electro-mechanical prototyping and testing which is performed by using real hardware on prototyping boards called breadboards shown in Figure 4. Breadboards are special tools with multiple wire sockets and internal conductive contact rails for building-running electronic circuits and systems. Circuits are assembled by installing electronic components on them and making the necessary connections with wires inserted into empty sockets. Several hand tools like cutters, pliers, and pieces of wire are required in the process.

For experimenting and simulation of product interior electronics, the Proteus 
software is used. While this PC program is mostly used for drawing electromechanical circuit schematics, it also has some other useful functions. Electronic components ranging from resistors to complex LCD screens and microprocessors are placed on the virtual workspace of the program, forming complete circuits whose operations can be realistically simulated. These circuits can range from simple electrical circuits with a battery, led and a switch to complex product systems with operational keyboards, dials, multimedia cards, speakers, Ethernet networks, USB connections and even microprocessors with their internal firmware codes are also executed in the simulation (Figure 11).

Proteus can also be used to convert circuit schematics to circuit boards to be printed or exported as 3-D models for use in other programs such as Solidworks. The exported 3-D circuit board model can be placed inside the virtual product assembly in Solidworks to check if its overall dimensions match to the dimensions of other parts sizes and positions of screw holes conform to the previously modeled product case.

For designing and producing Android applications, the Application Inventor System shown in Figures 8, 9, and 12, developed by Massachusetts Institute of Technology is used. This programming environment completely runs online and it has a powerful yet easy to use interface on which the students can easily create Android applications, store all required programming information in their personal account folders and when they want, easily transfer them to cell phones for testing and use. There is also the capability of uploading the apps to the Internet for both non-profit and commercial download and use of
Figure: II

Circuit schematic and the source code of "RetroGame" designed by the instructor.

Figure: 12

Application Inventor web interface, developed by MIT.
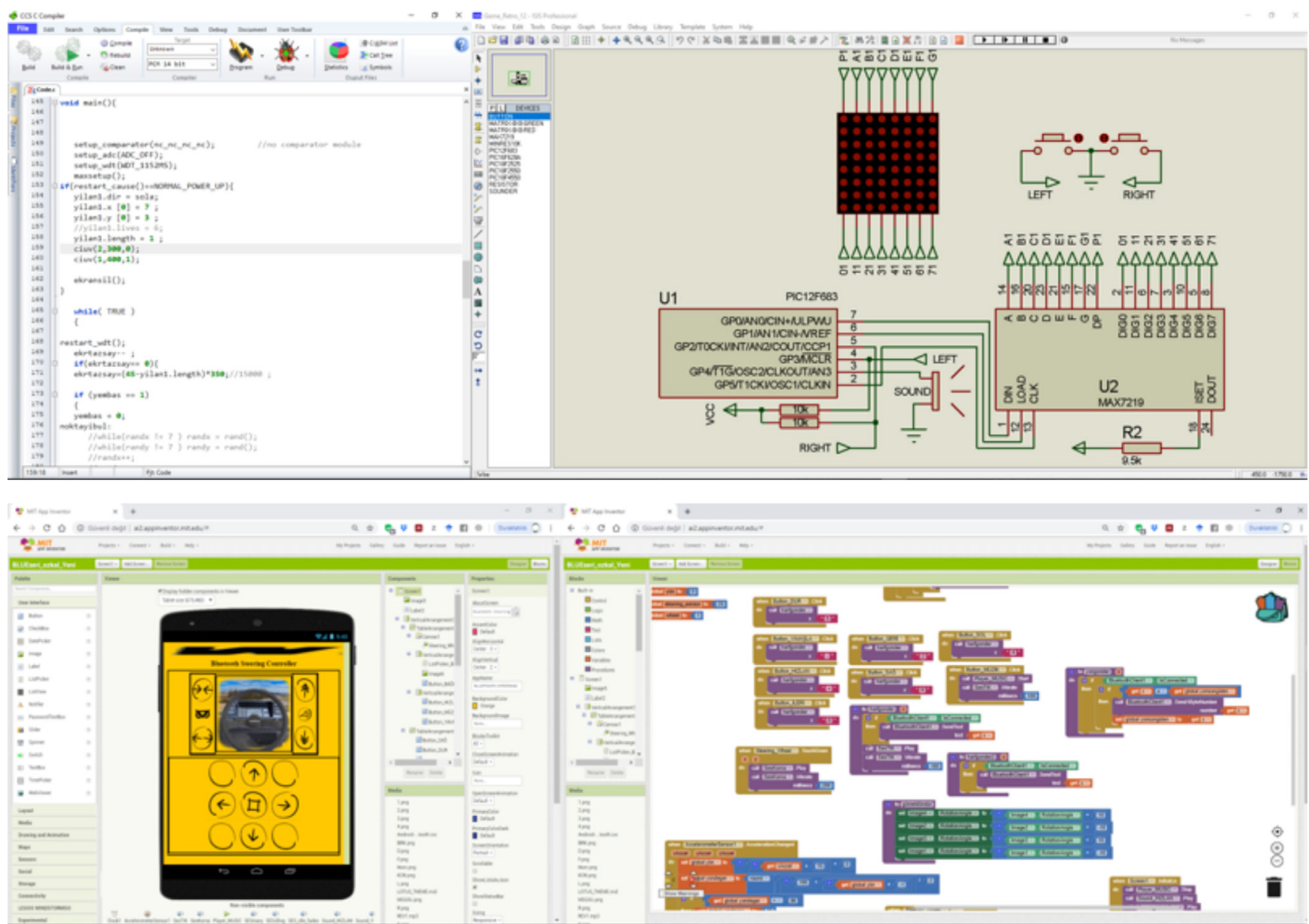
Figure: 13

Survey participant demographics (Age and Gender).
Table: I

Investigated skills and the Likert type scales used in the study.
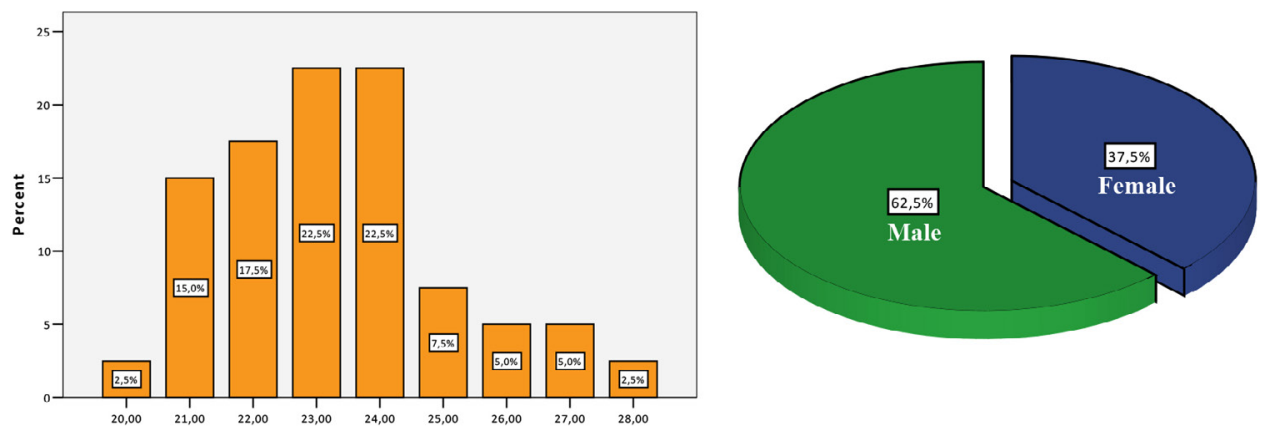

other people. This might create important business opportunities for a successful student.

\section{The Statistical Method Used in the Research}

Factor analysis method is used in this research to determine the factors that affect the necessity and outcomes of incorporating interdisciplinarity in industrial design education. Anonymous surveying, which is one of the most common and tested quantitative public data gathering methods, is used in the research while interviewing the participators. 120 volunteer students who took our lectures in the recent years formed the main mass of the research. 85 students among these 120 were selected by "simple random sampling" which gave each unit in the main mass a probability greater than zero to be selected as a sample. Information about the participants such as age, gender, etc. is used to form the overall demographics of the group (Figure 13).

For data gathering for the factor analysis, a table of skills is prepared that comprised of the general practices in Turkish professional industrial design which are expected to be improved by interdisciplinary design education. A second table is prepared to cover the improvements which are likely to be achieved in students' product design studio projects through interdisciplinary design education. Two Likert type scales and two separate directives are prepared to guide the participants during two phased interviews. The first directive is used for guiding the students while they state their opinions about the skills they gained and the second directive is used for guiding the students while they evaluate the achievements they made in their design studio projects.

For testing and verification purposes, pilot interviews are done with five students randomly selected among the samples. These interviews are used for acquiring feedback on the research method and led to some improvements on the questionnaire, guide directives, and the Likert scales that are listed below and in Table 1.

\begin{tabular}{|l|c|c|c|c|c|}
\hline \multirow{2}{*}{$\begin{array}{l}\text { Interdisciplinary Subjects } \\
\text { (Personal Gains) }\end{array}$} & \multicolumn{5}{|c|}{ Scale } \\
\cline { 2 - 6 } & $\mathbf{1}$ & $\mathbf{2}$ & $\mathbf{3}$ & $\mathbf{4}$ & $\mathbf{5}$ \\
\cline { 2 - 6 } & $\begin{array}{c}\text { Not Gained } \\
\text { Anything } \\
\text { At All }\end{array}$ & $\begin{array}{c}\text { Not Gained } \\
\text { Enough }\end{array}$ & Neutral & $\begin{array}{c}\text { Fairly } \\
\text { Important } \\
\text { Gains }\end{array}$ & $\begin{array}{c}\text { Very } \\
\text { Important } \\
\text { Gains }\end{array}$ \\
\hline Critical Perspective & & & & & \\
\hline Ability to Analyze & & & & & \\
\hline Finding Better Solutions to Problems & & & & & \\
\hline Increasing Technical Creativity & & & & & \\
\hline Better Concentration on Lessons & & & & & \\
\hline Organization Capability & & & & & \\
\hline Adapting to Teamwork & & & & & \\
\hline
\end{tabular}




\begin{tabular}{|l|l|l|c|c|c|}
\hline \multirow{2}{*}{$\begin{array}{l}\text { Design Project Class Gains } \\
\text { (Improvements to students' } \\
\text { product design studio projects) }\end{array}$} & \multicolumn{5}{|c|}{ Scale } \\
\cline { 2 - 6 } & Not At All & $\begin{array}{c}\text { Some But } \\
\text { Not Enough }\end{array}$ & Neutral & Enough & Satisfactory \\
\cline { 2 - 6 } & & & & & \\
\hline Production Safety & & & & & \\
\hline Cost Reduction & & & & & \\
\hline Facilitation of Production & & & & & \\
\hline Scenarios for Easier Use & & & & & \\
\hline Making More Durable Products & & & & & \\
\hline More Understandable Interfaces & & & & & \\
\hline Simplified Assembly Process & & & & & \\
\hline Applicability in Industry & & & & & \\
\hline Efficient Use of Technology & & & & & \\
\hline $\begin{array}{l}\text { Product Success Estimation by } \\
\text { Simulation }\end{array}$ & & & & & \\
\hline
\end{tabular}

Interview guide directives

(1) 'What do you think about the improvements you made on the listed skills due to the interdisciplinary lectures you attended? Please rate each skill on the list by using the given scale'.

(2) 'How much improvement do you think you have achieved in your design studio projects in terms of the given subject with the help of the interdisciplinary classes you attend? Please rate the improvement to each list item by using the given scale'.

\subsection{Findings}

\subsubsection{Exploratory Factor Analysis of the Abilities Gained By the Students}

To determine whether the gathered data is suitable for factor analysis, the Sphericity Test is used (Bartlett, 1950:77-85). The null hypothesis is accepted as the value of $\mathrm{p}=0,000$ obtained from the test being smaller than 0,05 indicated complete suitability. According to the findings in Table 3, the sample size for the explanatory factor analysis is sufficient as the Kaiser Meyer Olkin (KMO) coefficient is 0,805 .
Then exploratory factor analysis is applied with Principal Components Analysis and Varimax Rotation Techniques to examine the factor structure of the scale. The skill's measure of the factor increases with bigger loading (G. Tabachnick \& S. Fidell, 2007). Therefore skills having $50 \%$ and above relationship with the factor best describe the factor and its related scale, providing the most accurate assessment for the particular case. The rotated components matrix showing the factors obtained by explanatory factor analysis and the factor loads of the skills under these factors can be seen in Table 4 .

Two factors are determined by the analysis with corresponding individual variable loadings of at least 0,5 . As seen in Table, the eigenvalues of 2 factors are larger than 1 , and the total explained variance is $67,185 \%$.

An additional Cronbach $\alpha$ (Alpha) Analysis is conducted to ensure reliability in terms of internal consistency. This analysis produced coefficient numbers between 0-1 for the skill scales in all factors to show that they assess compatible skill properties and are consistent with each other. The calculated Cronbach $\alpha$ reliability
Table: 2

Investigated project improvements and the Likert type scales used in the study.

\begin{tabular}{|l|l|l|}
\hline Kaiser-Meyer-Olkin Measure of Sampling Adequacy. & 0,805 \\
\hline Bartlett's Test of Sphericity & Approx. Chi-Square & 241,478 \\
\cline { 2 - 3 } & $\mathrm{df}$ & 21 \\
\cline { 2 - 3 } & Sig. & 0,000 \\
\hline
\end{tabular}

Table: 3

KMO and Bartlett's Test. 
Table: 4

Rotated Component Matrix.

Table: 5

Factor Analysis Results for Students' Gains.

\begin{tabular}{|l|c|c|}
\hline \multirow{2}{*}{} & \multicolumn{2}{|c|}{ Component } \\
\cline { 2 - 3 } & $\mathbf{1}$ & $\mathbf{2}$ \\
\hline Critical Perspective & 0,800 & 0,204 \\
\hline Ability to Analyze & 0,779 & \\
\hline Finding Better Solutions to Problems & 0,734 & 0,403 \\
\hline Increasing Technical Creativity & 0,714 & 0,444 \\
\hline Better Concentration on Lessons & 0,156 & 0,854 \\
\hline Organization Capability & 0,245 & 0,789 \\
\hline Adapting to Teamwork & 0,234 & 0,715 \\
\hline $\begin{array}{l}\text { Extraction Method: Principal Component Analysis. } \\
\text { Rotation Method: Varimax with Kaiser Normalization. }{ }^{a}\end{array}$ \\
\hline a. Rotation converged in 3 iterations. & & \\
\hline
\end{tabular}

\begin{tabular}{|l|l|c|c|c|c|}
\hline $\begin{array}{l}\text { Scale } \\
\text { Subdimension }\end{array}$ & Skills & $\begin{array}{c}\text { Factor } \\
\text { Load Value }\end{array}$ & $\begin{array}{c}\text { Eigen } \\
\text { value }\end{array}$ & $\begin{array}{c}\text { Variance } \\
(\mathbf{\%})\end{array}$ & $\begin{array}{c}\text { Cumulative } \\
\text { Variance (\%) }\end{array}$ \\
\hline Factor 1 & Critical Perspective & 0,800 & 3,674 & 52,483 & 52,483 \\
\cline { 2 - 5 } & Ability to Analyze & 0,779 & & & \\
\cline { 2 - 6 } & $\begin{array}{l}\text { Finding More Correct Solutions } \\
\text { to Problems }\end{array}$ & 0,734 & & & \\
\cline { 2 - 6 } & Increasing Technical Creativity & 0,714 & & & \\
\hline \multirow{2}{*}{ Factor 2 } & Better Concentration for Lessons & 0,854 & 1.029 & 14,702 & 67.185 \\
\cline { 2 - 6 } & Organization Capability & 0,789 & & & \\
\cline { 2 - 6 } & Adapting to Teamwork & 0,715 & & & \\
\hline
\end{tabular}

Table: 6

Reliability Statistics.

Table: 7

KMO and Bartlett's Test.

\begin{tabular}{|c|c|c|}
\hline Cronbach's Alpha & Cronbach's Alpha Based on Standardized Items & N of Items \\
\hline 0,843 & 0,847 & 7 \\
\hline \multicolumn{2}{|l}{ The total $\alpha$ reliability coefficient of the 7 skills is found as $0,843}$. \\
\hline
\end{tabular}

\begin{tabular}{|l|l|l|}
\hline Kaiser-Meyer-Olkin Measure of Sampling Adequacy. & 0,899 \\
\hline Bartlett's Test of Sphericity & Approx. Chi-Square & 425,670 \\
\cline { 2 - 3 } & $\mathrm{df}$ & 45 \\
\cline { 2 - 3 } & Sig. & 0,000 \\
\hline
\end{tabular}

coefficient for the whole scale is given in Table 6.

\subsubsection{Exploratory Factor Analysis of the Improvements in Student Product Design Projects}

To determine whether the gathered data is suitable for factor analysis, the Sphericity Test is used (Bartlett, 1950:77-85). The null hypothesis is accepted as the value of $p=0,000$ obtained from the test being smaller than 0,05 indicated complete suitability. According to the findings in Table 7, the sample size for the explanatory factor analysis is sufficient as the Kaiser Meyer Olkin (KMO) coefficient is 0,899 .
Then exploratory factor analysis is applied with Principal Components Analysis and Varimax Rotation Techniques to examine the factor structure of the scale. The skill's measure of the factor increases with bigger loading (G. Tabachnick \& $S$. Fidell, 2007). Therefore, skills that had $50 \%$ and above relationship with the factor are thought to describe the factor and its related scale the best, providing the most accurate assessment for the particular case. The rotated components matrix showing the factors obtained by explanatory factor analysis and the factor loads of the skills under these factors can be seen in Table 8 . 


\begin{tabular}{|l|c|c|}
\hline \multirow{2}{*}{} & \multicolumn{2}{|c|}{ Component } \\
\cline { 2 - 3 } & $\mathbf{1}$ & 0,259 \\
\hline Production Safety & 0,842 & 0,157 \\
\hline Cost Reduction & 0,821 & 0,304 \\
\hline Facilitation of Production & 0,743 & 0,345 \\
\hline Scenarios for Easier Use & 0,666 & 0,490 \\
\hline Making More Durable Products & 0,646 & 0,410 \\
\hline More Understandable Interfaces & 0,607 & 0,806 \\
\hline Simplified Assembly Process & 0,220 & 0,769 \\
\hline Applicability in Industry & 0,361 & 0,755 \\
\hline Efficient Use of Technology & 0,222 & 0,532 \\
\hline Product Success Estimation by Simulation & 0,464 & \\
\hline $\begin{array}{l}\text { Extraction Method: Principal Component Analysis. } \\
\text { Rotation Method: Varimax with Kaiser Normalization. }{ }^{a}\end{array}$ & & \\
\hline a. Rotation converged in 3 iterations. & & \\
\hline
\end{tabular}

Table: 8

Rotated Component Matrix
Two factors are determined by the analysis with corresponding individual variable loadings of at least 0,5 . As seen in Table 9 , one of the eigenvalues is larger than 1 and the other one is very close to 1 and the total explained variance is $64,154 \%$.

An additional Cronbach $\alpha$ (Alpha) analysis is conducted to ensure reliability in terms of internal consistency. This analysis produced coefficient numbers between 0 - 1 for the skill scales in all factors to show that they assess compatible skill properties and are consistent with each other. The calculated Cronbach $\alpha$ reliability coefficient for the whole scale is given in Table 10 .

\section{Interpretation of the Findings}

This section presents the findings in figures 14-17 and interprets their implications as follows.

a. Students like to take part in interdisciplinary studies. These studies make students work on subjects out of their usual occupations, running their minds in different ways, therefore improving their mental capacity.

b. Students understand the virtues of being able to build running product circuits-systems, and they would like

\begin{tabular}{|c|c|c|c|c|c|}
\hline $\begin{array}{c}\text { Scale } \\
\text { Subdimension }\end{array}$ & Skills & $\begin{array}{c}\text { Factor } \\
\text { Load Value }\end{array}$ & $\begin{array}{l}\text { Eigen } \\
\text { value }\end{array}$ & $\begin{array}{l}\text { Variance } \\
(\%)\end{array}$ & $\begin{array}{c}\text { Cumulative } \\
\text { Variance (\%) }\end{array}$ \\
\hline \multirow[t]{6}{*}{ Factor 1} & Production Safety & 0,842 & 5.481 & 54.809 & 54.809 \\
\hline & Cost Reduction & 0,821 & & & \\
\hline & Production Facilitation & 0,743 & & & \\
\hline & Scenarios for Easy Use & 0,666 & & & \\
\hline & Making More Durable Products & 0,646 & & & \\
\hline & More Understandable Interfaces & 0,607 & & & \\
\hline \multirow[t]{4}{*}{ Factor 2} & Simplified Assembly Process & 0,806 & 0,934 & 9.345 & 64.154 \\
\hline & Applicability in Industry & 0,769 & & & \\
\hline & Efficient Use of Technology & 0,755 & & & \\
\hline & $\begin{array}{l}\text { Product Success Estimation by } \\
\text { Simulation }\end{array}$ & 0,532 & & & \\
\hline
\end{tabular}

\begin{tabular}{|c|c|}
\hline \multicolumn{1}{|c|}{ Cronbach's Alpha } & N of Items \\
\hline 0,907 & 10 \\
\hline The total $\alpha$ reliability coefficient of the 7 skills is found as $0,907$. \\
\hline
\end{tabular}

Table: 9

Factor Analysis Results for the Improvements in Student Design Projects.
Table: 10

Reliability Statistics. 
Figure: 14

Students' general expectations from the lectures (left) and the interest levels to various subjects covered (right).
Figure: 15

Improvements in the students' design projects through the lectures.

Figure: 16

Students' gains from the lectures.

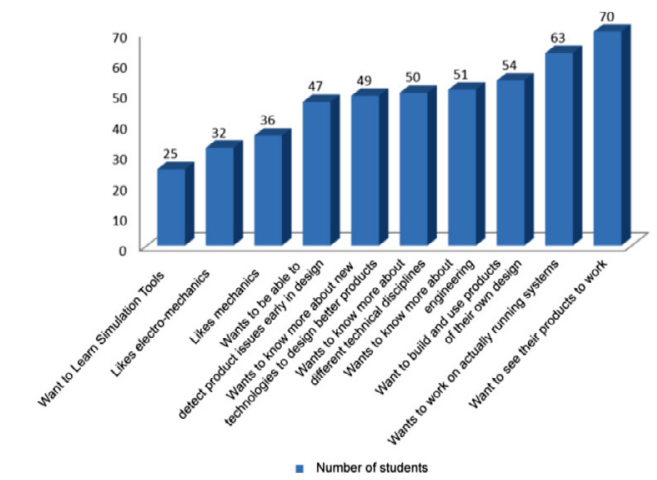

to use them in their product mockups (Figure 14).

c. Most of the students prefer design related hands-on activities instead of doing market research, logistics and purchasing (Figure 14).

d. Experience gained in the interdisciplinary studies is



n No, I didn't gain anything at all

no, I didn't feel any gains

In Neutral, don't have an idea

- Yes, some improvement is gained

nes, big improvement is gained

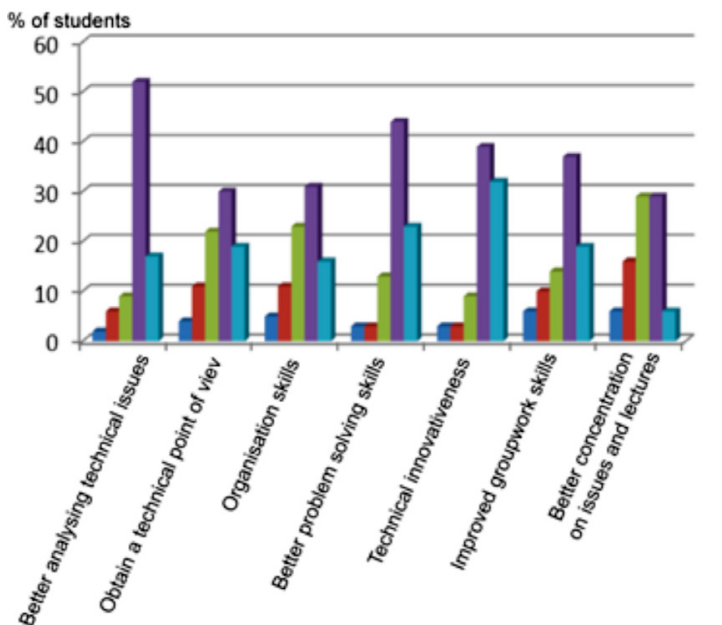

no, I didn't gain anything at all

no, I didn't feel any gains

neutral, don't have an idea

n Yes, some improvement is gained

- Yes, big improvement is gained

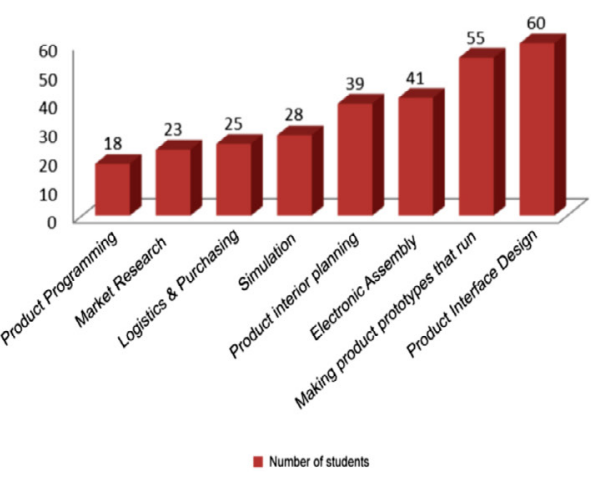

automatically utilized in students' other school activities and their daily lives. Interdisciplinary lectures in industrial design education help the students in their later professional lives in which they would need to work together with professionals from various disciplines (Figure 15).

e. Interdisciplinary knowledge gained through applied studies is more permanently learned by the students. They think that these studies will improve their school product design studio as well as being helpful in their later professional lives (Figure 16).

f. Students want their development to be the focus of education and expect the lecture activities to be arranged in a structure more comfortable for them. They think that the weekly time allocated for the lectures should be long enough to permit all activities of the lecture completed (Figure 17).

g. Students want to experience a gradually increasing amount of interdisciplinarity with advancing lectures spread into multiple semesters. They want the lectures to be related to each other and be supported with organized field trips to professional firms and universityindustry cooperation projects (Figure 17). They want to be confident in their interdisciplinary abilities and find good industrial design jobs after graduating.

h. The students want the lectures to take place in well-organized workshop 
environments and if possible in partnership with sponsor firms. They think that exchanging ideas with invited professionals from outsider firms or professors from other related university departments would improve their professional capabilities (Figure 17).

The factor analysis results in Table 5 show that the students' gains spread into two separate factor groups.

a. According to the skills it contained, the first factor group is named as "technical problem analysis" and it is related to having a critical perspective in analyzing technical problems and solving them. Having a "critical perspective" received the highest factor load value (hence the importance) in this group, followed by the "ability to analyze", then "finding correct solutions to problems", and "increasing technical creativity".

b. According to the skills it contained, the second factor group is named as "organization and teamwork" and it relates to forming teams to concentrate on the work at hand to achieve the best results. Within the factor group, "better concentration for lectures" received the highest factor load value, which is followed by "organization capability" and "adapting to teamwork".

The factor analysis results in Table 9 show that the improvements in student design studio projects spread into two separate factor groups.

a. According to the skills it contained, the first factor-group is named as "improvements in production and usage". The group generally relates to improving the design to facilitate easier production and use. Among the factors, "safety and cost reduction" received the highest factor load values which were followed by "simple production", "ease of use", "design for durability" and "better understandable product interfaces".

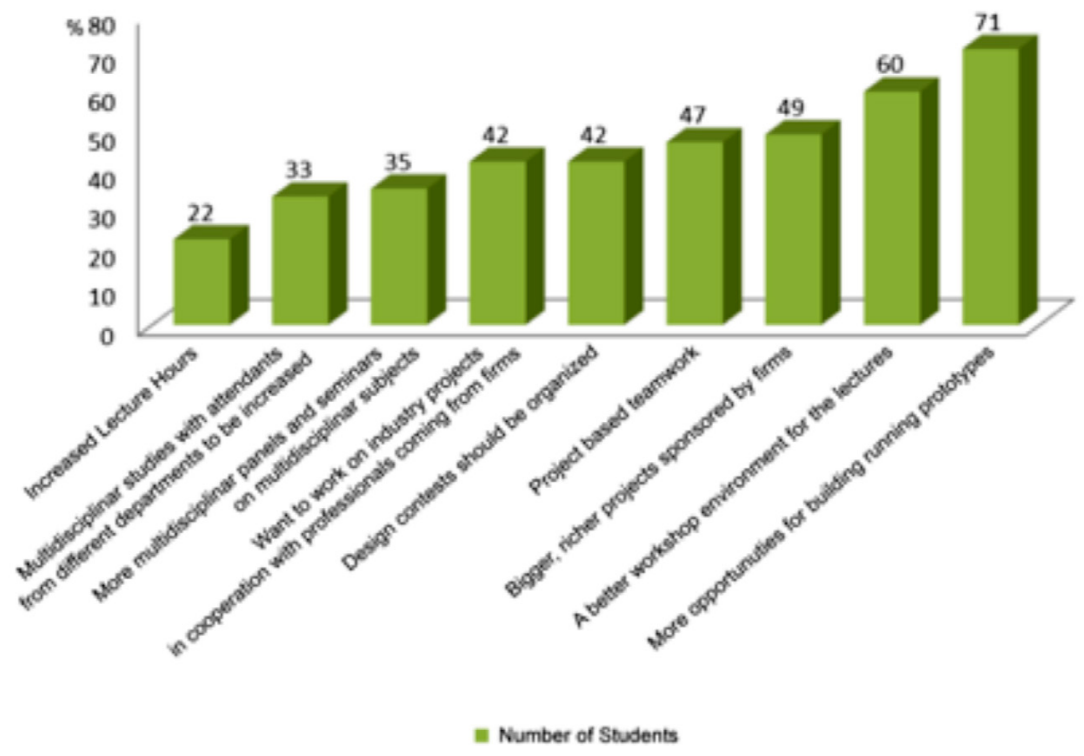

b. According to the skills it contained, the second factor-group is named as "Design for industry by Simulation".

Figure: 17 Students' thoughts about ways of improving interdisciplinary studies in industrial design education.
The group relates to the efficient use of simulation technologies for improving products' technology and manufacturability. Among the factors, designing for "simplified product assembly process" received the highest factor load value and it was followed by "industrial applicability", "efficient use of technology" and "product success estimation by simulation".

\section{Conclusion}

When we examined the earlier studies in literature, we saw that they mostly searched for information regarding to industrial designer employability and try to establish links between employability and quality of education than give conclusions and recommendations for designers to find better industrial design jobs and/or give recommendations for the education institutions to improve their education systems. Unfortunately, the studies seem to lack a clear and detailed definition of a method and/or list of rules to enable the design students to gain the abilities required for working in interdisciplinary environments efficiently and/or enabling the higher design institutions to make interdisciplinary studies an important 
part of their curriculums. This study aimed to give a clear and well-defined framework based on a case study about electro-mechanical and intelligent products design for use by industrial design students and industrial design institutions for the incorporation of interdisciplinary studies in industrial design education. In the article the framework containing lectures, workshops, data gathering and processing methods is described in detail. The efficiency of the proposed framework is evaluated by using factor analysis, performed on data gathered by interviewing the randomly selected students who took part in the studies. Then the details of the factor analysis process is explained and the resulted findings are presented as numerical results of the study. These results are further interpreted to produce conclusions demonstrating the benefits, importance, and necessity of the proposed framework.

The analysis results are organized within factor group tables, giving clear information about the student opinions about the study and interdisciplinary subjects in general. Most of the students $(93 \%)$ stated that this kind of approach was their preferred education method and said that they believe having this hands-on design and production experience would be helpful in their careers. In a supporting gesture for their stated opinions, majority of the students $(70 \%)$ took our later semester lectures also. As seen in the findings section, students think that interdisciplinary studies should take place at all possible phases of industrial design education.

While this applied interdisciplinary approach improves the technical capabilities of the students, it also gives them analytical thinking ability, which enables them to divide complex designdevelopment problem into smaller manageable parts, then solve it by cooperatively working on each part as a team. Simulation technologies introduced to students are also embraced by them and used throughout the study and hopefully will be used in their future professional careers. The methods used in the study enables the students to permanently learn the information given then remember and use them in their later professional careers. We believe students having this type of education can be expected to produce better, more efficient, technically advanced, and more industry applicable designs in their later careers 


\section{Kaynakça}

Bartlett, M. S. (1950). Tests of Significance in Factor Analysis. British Journal of Statistical Psychology, 3(2), 77-85. https://doi.org/10.1111/j.2044-8317.1950.tb00285.x

Başar, A. G. C.., \& Ülkebaş, D. (2011). Diversity of industrial design education in Turkey and future prospects. Procedia - Social and Behavioral Sciences, 15, 981-987. https://doi.org/10.1016/j. sbspro.2011.03.225

Cartier, P. (2011). Most valuable aspects of educational expectations of the students in design education. Procedia - Social and Behavioral Sciences, 15, 2187-2191. https://doi.org/10.1016/j. sbspro.2011.04.077

Erkarslan, O. (2013). A systematic review of the relations between industrial design education and industry in Turkey through SWOT analysis. Design Journal (Vol. 16). https://doi.org/10.2752/1756306 $13 \mathrm{X} 13512595146952$

Erkarslan, O., Kaya, N. A., \& Dilek, O. (2013). Comparative analysis of recruitment qualifications of industrial designers in Turkey through undergraduate education programs and online recruitment resources. International Journal of Technology and Design Education, 23(1), 129-145. https://doi. org/10.1007/s10798-011-9164-6

Etemoğlu, Ş. (2013). Türkiye'de Firmalarda İstihdam Edilen Endüstri Ürünleri Tasarımcılarının Motivasyon Faktörleri [Motivation Factors of Industrial Designers Employed by Companies in Turkey]. Istanbul Technical University. Retrieved from https://polen.itu.edu.tr/handle/11527/870

Findeli, A., Brouillet, D., Martin, S., Moineau, C., \& Tarrago, R. (2008). Research Through Design and Transdisciplinarity: A Tentative Contribution to the Methodology of Design Research. In H. Lysianne, Léchot (Ed.), 'Focused'-Current Design Research Projects and Methods (pp. 67-91). Mount Gurten, Berne.

G. Tabachnick, B., \& S. Fidell, L. (2007). Using Multivariate Statistics. (S. Hartman, Ed.), Pearson Education, Inc. (5th ed.). Boston: Pearson Publishing. Retrieved from https:// dl.acm.org/citation.cfm?id=1213888

Gibbons, M. (1994). The new production of knowledge. The dynamics of science and research in contemporary societies. London: Sage Publications.

Itkonen, M., Ekman, K. E., \& Kojo, I. (2009). Murjottelu -interdisciplinary training campaign for industrial design and engineering students. European Journal of Engineering Education, 34(3), 263271. https://doi.org/10.1080/03043790903038858

Jantsch, E. (1972). Inter and Transdisciplinary University: a Systems Approach To Education and Innovation. Higher Education Quarterly, 1(1), 7-37. https:// doi.org/10.1111/j.1468-2273.1947.tb02067.x

Kınd1, M. (2007). Türkiye'de endüstriyel tasarim iş piyasasi ve istihdam düzeyinde temel karakteristikleri [Industrial Design Job Market in Turkey and its Basic Employment Characteristics]. İstanbul Technical University. Retrieved from https:// polen.itu.edu.tr/xmlui/handle/11527/927

Lowden, K., Hall, S., Elliot, D., \& Lewin, J. (2011) Employers' perceptions of the employability skills of new graduates. Edge/SCRE Centre. Retrieved from https:/www.educationandemployers.org/ wp-content/uploads/2014/06/employability_ skills as pdf - final online version.pdf
Nicolescu, B. (2005). Towards transdisciplinary education. The Journal for Transdisciplinary Research in Southern Africa, 1(1), 11. https://doi.org/10.4102/ td.v1i1.300

Oakes, G. L., Felton, A. J., \& Garner, K. B. (2006). 'From the formal to the innovative': The use of case studies and sustainable projects in developing a design process model for educating product/ industrial designers. European Journal of Engineering Education, 31(5), 567-579. https:// doi.org/10.1080/03043790600797467

Sloka, B., Kantāne, I., Buligina, I., Tora, G., Dzelme, J., \& Buševica, R. (2015). Employers' Needs and Expectations for Qualified Employees ( Case Study on the Opinions in One of the Regions in Latvia ). Economics and Business, 27(1), 69-75. https://doi.org/10.1515/eb-2015-0011

Sonnenwald, D. H., \& Lievrouw, L. A. (1997). Collaboration during the design process: a case study of communication, information behavior, and project performance. Information Seeking in Context. Retrieved from http://www.researchgate. net/publication/234813706_Collaboration_during_the_design_process_a_case_study_of_communication information behavior and project_performance/file/32bfe $512 \mathrm{fdc} 355 \mathrm{a} 7 \mathrm{c} 0 . \mathrm{pdf}$

Srinivasan, V., Lovejoy, W. S., \& Beach, D. (1997). Integrated Product Design for Marketability and Manufacturing. Journal of Marketing Research, 34(1), 154-163. https://doi.org/10.2307/3152072

Tsitskari, E., Goudas, M., Tsalouchou, E., \& Michalopoulou, M. (2017). Employers' expectations of the employability skills needed in the sport and recreation environment. Journal of Hospitality, Leisure, Sport and Tourism Education, 20(September 2016), 1-9. https://doi. $\operatorname{org} / 10.1016 /$ j.jhlste.2016.11.002

Wang, K. (2008). Research of the recruiting qualifications of the ID profession and their implication in ID education. 9th International Conference on Computer-Aided Industrial Design and Conceptual Design: Multicultural Creation and Design - CAIDCD 2008, 851-854. https://doi. org/10.1109/CAIDCD.2008.4730694

Weligamage, S., \& Siengthai, S. (2003). Employer Needs and Graduate Skills: The Gap between Employer Expectations and Job Expectations of Sri Lankan University Graduates. In 9th International conference on Sri Lanka Studies. Retrieved from https://www.researchgate.net/ publication/275344087_Employer_Needs_and Graduate_Skills_The_Gap_between_Employer Expectations and Job Expectations of Sri Lankan_University_Graduates

Yarimca, Ö. (2011). Disiplinler arası yaklaşıma dayalı bir durum çalıșması [A Case Study Based on Interdisciplinary Approach]. Akademik Bakıs, (25), 1-22. Retrieved from http://www.acarindex. com/dosyalar/makale/acarindex-1423868125.pdf 